\title{
Editorial
}

\section{Arte e Medicina}

\section{Art and Medicine}

Olavo Franco Ferreira Filho ${ }^{10}$

Medicina é a ciência e a arte de "curar os doentes e aliviar o sofrimento". No entanto, a especialização e o rápido avanço do conhecimento e da tecnologia afastam a atenção de professores e estudantes do propósito central da medicina. Os pacientes reclamam que os médicos os tratam como objetos inanimados e que serão analisados por um computador, máquinas de tomografia e ressonância magnética. Eles querem ter tempo para conversar e ter contato físico com o médico.

A medicina exige conhecimento científico, que será aplicado à beira do leito. Mas o conhecimento por si só não é suficiente para aliviar o sofrimento. É preciso, também, desenvolver e praticar habilidades e atitudes à beira do leito para ganhar a confiança do paciente e aumentar sua adesão ao tratamento.

Boas práticas à beira do leito são a essência da arte da medicina. As escolas estão descobrindo que ensinar as artes aos estudantes de Medicina os ajuda a aprimorar suas habilidades de observação e os ensina a ser mais empáticos. A empatia é "a capacidade de estar ciente dos sentimentos e emoções de outras pessoas". Empatia não é o mesmo que simpatia, que é "sentir por alguém". Professores e estudantes precisam de empatia para entender os pacientes.

Arte e medicina caminham juntas há muito tempo. Leonardo da Vinci, por exemplo, dissecava corpos para tornar seus trabalhos perfeitos. Em todo o mundo, universidades estão usando algumas obras-primas para ajudar os estudantes a compreender melhor a anatomia humana, a reconhecer sintomas e a desenvolver qualidades importantíssimas para um bom médico - a capacidade de observação.

Nos Estados Unidos, a Escola de Medicina do Monte Sinai, em Nova York, leva os estudantes ao Metropolitan Museum. Lá está, por exemplo, a tela "Abraão Expulsando Hagar e Ismael", do holandês Nicolaes Maes. A obra retrata uma passagem bíblica segundo a qual Abraão manda embora a escrava Hagar e o filho que teve com ela, Ismael. Enquanto percorrem o museu, os estudantes são estimulados a observar o quadro. O objetivo dos professores, nesse caso, é fazer os jovens refletirem sobre os prejuízos de uma decisão errada. Ao mandar os dois para longe e ficar apenas com seu filho legítimo, Isaac, Abraão acabou dando início a uma das grandes cisões mundiais: Ismael deu origem ao povo árabe, e Isaac, ao povo judeu.

São poucos ainda os trabalhos que medem os resultados deste tipo de iniciativa para o cotidiano médico. Um dos maiores esforços das escolas de Medicina é fazer com que os alunos consigam realizar um retrato integral do paciente e não apenas avaliar sua queixa pontual. Com a ajuda da arte, o médico passa a ver o doente com um olhar mais apurado, a lidar com as incertezas, a enxergar detalhes que poderão ajudar no diagnóstico. 
Neste número da Revista Brasileira de Educação Médica, temos um artigo que se propõe fazer uma revisão da literatura sobre a aplicação das artes na prática médica e que, com certeza, despertará o interesse daqueles que desejam introduzir em suas grades curriculares essa importante estratégia de aprendizado.

\section{REFERÊNCIAS}

1. Monahans L, Monahan D, Chang L. Applying art observations skills to standardized patients. Applied Nursing Research 2019; 48: 8-12.

2. Hajar R. What as art to do with medicine? Heart Views; 19(1):34-35.
ENDEREÇO PARA CORRESPONDÊNCIA

Associação Brasileira de Educação Médica - Abem

SCN Quadra 2, Bloco D, Sala 1021, Asa Norte - Brasília

CEP 70712-903 - DF

\section{CONFLITO DE INTERESSES}

Autor declara não haver.

Recebido em: 25/7/19

Aceito em: 25/7/19 